\title{
ANALIZA UPORABE FINANCIJSKE POLUGE U PODUZEĆU „HRVATSKE ŠUME“ D.0.0.
}

\section{ANALYSIS OF USING A FINANCIAL LEVERAGE IN COMPANY „HRVATSKE ŠUME“, LTD}

Damir KLOBUČAR ${ }^{1 *}$, Silvije ORSAG²

\begin{abstract}
SAŽETAK
Uspjeh poslovanja za vlasnike poduzeća ovisi o postignutoj snazi zarađivanja, ali i o izboru oblika financiranja poslovanja poduzeća. Sumarno se oportunost izbora oblika financiranja može promatrati preko pravila financijske poluge. Pravilo govori o tome kako se oportunom uporabom dugova može povećati prinos za vlasnike prema prinosu koje bi imali da se dugovi nisu koristili. U radu su najprije analizirani mogući pristupi analizi oportunosti uporabe financijske poluge i izoliran je kao najbolji pristup onaj koji isključuje zamku spontanog financiranja. Nakon toga primijenjena je analiza na konkretne podatke poduzeća Hrvatske šume d.o.o. u razdoblju 2005.-2015. Analiza je pokazala kako u Hrvatskim šumama d.o.o., osim u zadnjoj godini analiziranog razdoblja, uporaba financijske poluge nije bila oportuna. Pri tome je ključni razlog za neodgovarajuće zaduživanje izrazito slaba snaga zarađivanja u najvećem dijelu analiziranog razdoblja, dok su na to samo ograničeno utjecali skupi dugovi.
\end{abstract}

KLJUČNE RIJEČI: šumarstvo, efekt financijske poluge, profitabilnost vlastitog kapitala, profitabilnost imovine, trošak duga

\section{UVOD}

\section{INTRODUCTION}

Struktura kapitala poduzeća najčešće se predočuje odnosom duga i glavnice, odnosno odnosom tuđeg i vlastitog kapitala. U tom se smislu ključni problem strukture kapitala može izraziti pitanjem: utječe li zaduživanje na vrijednost poduzeća? Dva su moguća odgovora: da ili ne, a ako utječe, moguća su tri daljnja odgovora: Je li taj utjecaj zaduživanja povoljan ili, pak nepovoljan, te postoji li neka optimalna struktura kapitala koja rezultira najvećom vrijednošću poduzeća. Upravo ovo pitanje i razni mogući odgovori jedno su od ključnih kontroverzi suvremenih financija koju je Myers (1984) nazvao zagonetkom strukture kapitala (Capital structure puzzle).

Uporaba financijske poluge ili, jednostavnije uporaba poluge, često se rabi kao sinonim za zaduživanje poduzeća, odnosno financiranje nekog posla visokim udjelom dugova (Orsag 2015). O financijskoj poluzi može se raspravljati na više načina. Jedan je u okviru teorije strukture kapitala poduzeća koju je započeto David Durand (1952) formulirajući tri pristupa, među kojima je tzv. tradicionalni pristup rezultat pretežnog stava akademske i stručne zajednice. Revoluciju u teoriji strukture kapitala pokrenuli su Modigliani i Miller (1958., 1963.i 1969.) analizirajući strukturu kapitala u kontekstu potpuno učinkovitog, odnosno savršenog tržišta, te mogućnošću da se napuštanjem pojedinih rigidnih pretpostavki savršenog tržišta analiziraju utjecaji stvarnog svijeta na oblikovanje strukture kapitala. Na podlozi tih radova nastala je Teorija kompromisa, a uvođenjem elemenata odlučivanja o oblikovanju strukture kapitala i druga temeljna teorija, Teorija hijerarhije financijskih izbora. Obje ove teorije formulirane su u radu Shyam-Sunder i Myers (1999). Uz ove dvije dominantne teorije govori se i o onima

${ }^{1}$ Dr. sc. Damir Klobučar, Hrvatske šume d.o.o., Zagreb (damir.klobucar@hrsume.hr) * Autor za korespondenciju

${ }^{2}$ Prof. dr. sc. Silvije Orsag, Sveučilište u Zagrebu, Ekonomski fakultet, Katedra za ekonomiku poduzeća 
koje se temelje na signaliziranju (Akerlof 1970) i koje se temelje na problemu agenata (Jenseni i Mackling 1976). U novije vrijeme razvijene su i teorije temeljene na proizvodnim i tržišnim interakcijama, na korporacijskog kontroli i na tržišnom trendu (Pecina 2018). Teorije strukture kapitala dale su podlogu za izoliranje osnovnih čimbenika strukture kapitala. Slijedom tih teorija danas se provodi njihovo testiranje na različitim uzorcima.

Jedan dio istraživanja ispituje teorije strukture kapitala anketnim upitnicima. Većina tih istraživanja inspirirana je radom Grahama i Harveya (2001). Drugi pravac analize fenomena financijske poluge usredotočuje se na ispitivanja signifikantnosti i smjera utjecaja različitih čimbenika strukture kapitala. Kao svojevrsni stožerni rad na ovome području može se izdvojiti Rajan i Zingales (1995). Treći pravac testiranja teorija strukture kapitala koristi različite statističke modele. Ključnim radom na ovome području može se označiti Shyam-Sunder i Myers (1999). Naime, tek je u ovome radu predstavljena mogućnost testiranja obje ključne teorije strukture kapitala, dakle, teorije kompromisa, koja se je testirala i ranije, kao i teorije hijerarhije financijskih izbora.

Središnja misao pravila financijske poluge nalazi se u činjenici da se oslanjanjem na dugove u financiranju poslova i poslovanja poduzeća mogu ostvariti veći učinci za vlasnike poduzeća, s obzirom na one koji bi se ostvarili da je cjelokupno poslovanje poduzeća financirano isključivo vlasničkom glavnicom (Orsag 2015). Pozitivni utjecaj poluge ogleda se u tri bitna čimbenika: (i) većim udjelom tuđeg financiranja smanjuje se udjel vlastitog kapitala te se sukladno nepromijenjenoj ukupnoj profitabilnosti povećava profitabilnost vlastitog kapitala, (ii) kamate predstavljaju fiksni teret financiranja pa je kod viših razina poslovne aktivnosti njihov udio u ukupnim troškovima relativiziran, što ponovno djeluje na višu profitabilnost vlastitog kapitala, (iii) kamate predstavljaju porezni odbitak u rezultatu poslovanja, pa su moguće porezne uštede zbog korištenja tuđih izvora financiranja (Dvorski i Kovšca 2011).

Navedene prednosti djeluju samo u slučaju da je uporaba financijske poluge bila oportuna, uspješna. Upotreba financijske poluge je uspješna ako se na imovinu zarađuje viši prinos nego što je kamatna stopa na posuđena sredstva. U slučaju da korištenje financijske poluge nije bilo uspješno, poduzeće zarađuje za svoje vlasnike manje nego da se nisu koristili dugovi. Tada poduzeće na posuđena sredstva plaća kamate po kamatnoj stopi višoj od prinosa na imovinu (ROA). Kako se kamate moraju platiti prema odredbama ugovora o kreditu prije bilo kakve raspodjele ukupnih zarada, kreditorima će se iz ukupnih zarada isplatiti veći iznos od onoga koji je poduzeće zaradilo na posuđena sredstva, što će smanjiti prinos vlasnika ispod onog koji odgovara prinosu na imovinu. To znači da uzimajući preskupe kre- dite prema snazi zarađivanja menadžment raditi na štetu, a ne u korist svojih vlasnika.

Dakle, od prvih istraživanja problema strukture kapitala poduzeća (Durand 1952.), preko takozvane Modigliani Millerove revolucije i formiranih osnovnih i iz njih izvedenih teorija strukture kapitala (Pecina i Orsag 2014., Pecina 2018.), znanstvenici su pokušavali utvrditi isplati li se zaduživati i postoji li optimalna razina duga poduzeća. Najjednostavniji pristup tome pitanju nalazi se u klasičnom pravilu financijske poluge.

$\mathrm{U}$ ovome radu analiziran je fenomen financijske poluge $\mathrm{u}$ svome „klasičnom“" obliku pravila financijske poluge, koje predstavlja nedvojbeni financijski standard uključen u sve udžbenike s područja poslovnih financija, odnosno financija dioničkih društava (Helfert 1991., Brealey i dr. 2001., Gitman 2002.). Za ovaj pristup analize financijske poluge odlučili smo se jer se rijetko razmatra u području ekonomike šumarstva, a značajan je za procjenu oportunosti korištenja financijske poluge u poduzećima, pa tako i u onima u djelatnosti šumarstva (Klobučar 2018, Klobučar i Orsag 2018). Osim želje da se ocijeni gospodarenje dugovima u poduzeću „Hrvatske šume“ d.o.o., ideja rada je da se udžbenički pristup analizi poluge razradi za konkretnu uporabu. Naime, u udžbenicima se najčešće analiza financijske poluge razmatra u kontekstu dugoročne strukture kapitala formirane dionicama i obveznicama. Taj pristup potrebno je prilagoditi za analizu, ako ni zbog čega drugoga onda zbog postojanja spontanog financiranja. Nadalje, oportunost financijske poluge često se analizira različitim financijskim pokazateljima. Kako su i oni opterećeni složenošću financijskih struktura poduzeća, nastoje se izgraditi novi pokazatelji koji bi ispravnije razgraničili oportunu od neoportune financijske poluge. Primjer toga su Deo i Mukherjee (2007. navedeno u Lízalová i Kozáková 2013.) te Ježovita i Žager (2014.). Kako i ovi pokazatelji imaju određenih slabosti, u radu smo izgradili svoj model analize oportunosti upotrebe financijske poluge koji bolje razgraničava oportuno od neoportunog korištenja financijske poluge, jer daje uvid u performanse poduzeća uz uporabu poluge u odnosu na one koje bi bile da se poluga nije uopće niti koristila.

\section{MJERE KORIŠTENJA FINANCIJSKE POLUGE FINANCIAL LEVERAGE MEASUREMENTS}

Samu uspješnost korištenja financijske poluge moguće je mjeriti na različite načine.

Intenzitet uporabe poluge može se iskazivati korištenjem dva osnovna pokazatelja: stupnjem zaduženosti poduzeća i odnosom duga i glavnice (D/E) poduzeća.

$$
\text { Stupanjzaduženosti }=\frac{\text { ukupneobveze }}{\text { ukupnaimovina }}
$$


Stupanj zaduženosti predstavlja udjel ukupnih obveza poduzeća u ukupnoj imovini. Pokazuje koliki se dio ukupne imovine poduzeća financira dugovima. Što je veći stupanj zaduženosti poduzeće je zaduženije, odnosno intenzivnije koristi polugu i obrnuto. Stupanj zaduženosti može se mjeriti i samo za kamatonosne obveze, kao i samo za dugoročne dugove. $U$ tom slučaju potrebno je ukupnu imovinu umanjiti za spontano financiranje (financiranje koje nastaje spontano uobičajenim načinom poslovanja i plaćanja određenih obveza, kao što su uobičajeni trgovački krediti dobavljača, zbog čega je ovaj oblik financiranja, u pravilu, besplatan, odnosno bez kamata) (Orsag 2011), a u drugoj inačici mjerenja za kratkoročno financiranje.

$$
\frac{D}{E}=\frac{\text { dugovi }}{\text { glavnica }}
$$

Odnos duga i glavnice izvorno promatra odnos dugoročnih dugova i vlasničke glavnice poduzeća. Ovaj se odnos može računati i za sve kamatonosne obveze koje se stavljaju u odnos s vlasničkom glavnicom, pa je komplementaran s inačicom stupnja zaduženosti koji iz računa izostavlja dio imovine koji se financira spontano. Ako se ovaj odnos računa kao ukupne obveze, bit će komplementaran sa stupnjem zaduženosti kako je prikazano formulom 1 . Ponekad se intenzitet uporabe poluge mjeri i odnosom glavnice i dugova kao recipročnim pokazateljem odnosa duga i glavnice.

Standardna analiza učinka financijske poluge je EBIT/EPS analiza (Gitman 2002). Tu se promatra utjecaj zarada prije kamata i poreza (Earnings Before Interest and Taxes - EBIT) na zarade po dionici (Earnings Per Share - EPS). Kako zarade po dionici predstavljaju odnos zarada za dioničare, dakle zarada nakon kamata i poreza (Earnings After Interest and Taxes - EAT), moguće je umjesto analize EBIT/EPS provesti analizu EBIT/EAT za poduzeća koja nisu organizirana kao dionička društva. Kod zaduženog poduzeća EPS (EAT) se brže mijenjaju od promjene EBIT koje su ih izazvale. To znači da su zarade po dionici (zarade nakon kamata i poreza) to osjetljivije na promjene ukupnih zarada što je uporaba poluge odnosno zaduženost veća. Veća osjetljivost zarada po dionici na promjene ukupnih zarada znači da je njihova distribucija vjerojatnosti raspršenija od raspršenosti distribucije vjerojatnosti ukupnih zarada. Kako se distribucijom vjerojatnosti standardno mjeri rizik u financijama (Orsag 2011.), zaduženost proizvodi dodatni financijski rizik za dioničare zadužene od rizika koji imaju dioničari nezaduženog poduzeća.

Osjetljivost, odnosno elastičnost EPS (EAT) na promjene EBIT mjeri se stupnjem financijske poluge (Degree of Financial Leverage - DFL) koji predstavlja odnos EBIT prema EBT (Earnings Before Taxes):

$$
D F L=\frac{E B I T}{E B T}
$$

Stupanj financijske poluge uvijek je veći od jedan ako je riječ o zaduženom poduzeću koje ostvaruje dobit. To znači da se zarade po dionici mijenjaju brže od promjena zarada. Međutim, stupanj financijske poluge smanjuje se s povećanjem razine zarada na kojima se računa. To znači da su profitabilnija poduzeća manje osjetljiva na zaduživanje od onih manje profitabilnih, čime se potvrđuje kako je visoka i stabilna profitabilnost jedan od ključnih preduvjeta uspješnog korištenja dugova.

Analiza učinka financijske poluge može se obaviti i usporedbom profitabilnosti ukupne imovine i kamatne stope na dugove, odnosno ukupne obveze. Prva veličina može se mjeriti odnosom EBIT i ukupne imovine ili odnosom EAT, uvećanih za kamate, i ukupne imovine, iako je prva mjera logičnija i preciznija jer bolje tretira porezni zaklon. Kamatna stopa mjeri se odnosom ukupnih kamata i ukupnih obveza (Orsag 1982). U tom je smislu uporaba poluge oportuna, ako je ostvarena profitabilnost imovine $(R)$ viša od kamatne stope na dugove poduzeća $(k)$, odnosno ako je:

$$
R>k
$$

Problem $R / k$ usporedbe je što zaključke može iskriviti utjecaj spontanog financiranja. Naime, spontano financiranje je uglavnom besplatno, pa povećava iskazanu oportunost uporabe poluge ako se uključi u ukupne obveze poduzeća. Zbog toga je potrebno ukupnu imovinu umanjiti za spontano financiranje kod izračuna profitabilnosti imovine, a ukupne obveze kod izračuna prosječne kamatne stope. Drugi mogući pristup korekcije pretpostavki usporedbe $R / k$ je da se izračun bazira isključivo na (dugoročnoj) kapitalizaciji poduzeća. To znači da imovinu treba umanjiti za cjelokupno kratkoročno financiranje, a za izračun kamatne stope treba koristiti samo kamate na dugoročne dugove $\mathrm{u}$ odnosu na dugoročne dugove.

Jedna od mogućih mjera oportunosti financijske poluge je efekt financijske poluge (Effect of Financial Leverage - EFP). EFP predstavlja ostvareno povećanje ili smanjenje profitabilnosti vlastitoga kapitala uslijed korištenja dugova za financiranja. EFP je umnožak financijske poluge $(F P)$ i razlike neto profitabilnosti imovine (RIN) i stope troška dugova, odnosno ukupnih obveza (STTK). Negativna vrijednost pokazatelja ukazuje na smanjenje profitabilnosti vlastitoga kapitala uslijed korištenja dugova. Pozitivna vrijednost toga pokazatelja znači povećanje profitabilnosti vlastitoga kapitala korištenjem dugova. Što je efekt veći, povećanje profitabilnosti vlastitoga kapitala je značajnije (Ježovita i Žager 2014).

\section{MATERIJALI I METODE MATERIAL AND METHODS}

Za ispitivanje utjecaja financijske poluge korišteni su pokazatelji profitabilnosti imovine poduzeća. Profitabilnost vla- 
stitog kapitala (ROE) stavlja u odnos neto dobit (EAT) i vlastiti kapital (glavnicu), a pokazuje koliko je učinkovito korišten vlastiti kapital poduzeća. Profitabilnost imovine (ROA) stavlja u odnos bruto dobit (EBIT) i ukupnu imovinu, a ukazuje koliko profita poduzeće ostvari po jedinici uložene imovine. Alternativno, profitabilnost imovine može se mjeriti kao odnos neto dobiti i kamata prema ukupnoj imovini (RIN). Ova alternativna mjera profitabilnosti imovine korištena je za izračun efekta financijske poluge. Izračuni ova tri pokazatelja profitabilnosti prikazan je u tablici 1 .

Table 1: Pokazatelji profitabilnosti

Table 1: Profitability ratios

\begin{tabular}{ccc} 
Pokazatelj & Brojnik & Nazivnik \\
\hline ROA & bruto dobit & ukupna imovina \\
& EBIT & \\
RIN & neto dobit + kamate & ukupna imovina \\
& EAT + I & \\
ROE & neto dobit & vlastiti kapital (glavnica) \\
& EAT &
\end{tabular}

Profitabilnost glavnice ovisi o profitabilnosti ukupne imovine i o intenzitetu korišstenja poluge. Što je profitabilnost imovine viša, viša će biti i profitabilnost glavnice. Ako je uporaba financijske poluge oportuna, profitabilnost glavnice bit će to viša od one koja bi bila bez uporabe poluge, što je intenzivnije korištena poluga i obrnuto. Naravno, ako uporaba poluge nije bila oportuna, profitabilnost glavnice biti će to niža što je intenzitet uporabe poluge bio veći.

Efekt financijske poluge je izračunat korištenjem formule (Ježovita i Žager 2014):

$$
\mathrm{EFP}=(\mathrm{RIN}-\mathrm{STTK})^{\star} F P(4)
$$

Gdje je:

$$
\begin{gathered}
\text { RIN }=\frac{\text { Neto Dobit }+ \text { Rashodiod Kamata }}{\text { Ukupnaimovina }} \\
\text { STTK }=\frac{\text { Rashodi od kamata }}{\text { Ukupne obveze }} \\
F P=\frac{\text { Ukupne obveze }}{\text { Vlasnička Glavnica }}
\end{gathered}
$$

Kvaliteta korištenja dugova, odnosno posuđenih financijskih sredstava, mjerena je, osim efektom financijske poluge, ROA i ROE analizom. Standardna analiza ROA i ROE proširena je uključivanjem $u$ analizu spontanog financiranja $i$ obveza koje nose kamate (KO) te redefiniranjem ukupne imovine (UI) i vlasničke glavnice (VG). Spontanim financiranjem u radu su obuhvaćeni dobavljači (D). Obveze koje nose kamate odnose se na:
- dugoročne obveze prema bankama i drugim financijskim institucijama

- dugoročne obveze po osnovi zajmova

- kratkoročne obveze prema bankama i drugim financijskim institucijama

- kratkoročne obveze po osnovi zajmova.

Tim slijedom analiza ROA provedena je stavljajući u odnos bruto dobit - EBIT s ukupnom imovinom u prvom slučaju (Izraz 5), odnosno sa sumom VG i KO u drugom slučaju (Izraz 8) i u trećem slučaju s odnosom sume VG, KO i D (Izraz 11). Shodno navedenom, analiza ROE provedena je s polugom i bez poluge, također $\mathrm{u}$ tri slučaja. $\mathrm{U}$ analizi s polugom neto dobit stavljena je u odnos s VG $(\operatorname{Izraz} 6,9,12)$ odnosno $u$ analizi bez poluge bruto dobit umanjena za porez stavljena je u odnos sa redefiniranom VG $(\operatorname{Izraz} 7,10,13)$.

I. Slučaj (Case)

$$
\begin{gathered}
R O A(I)=\frac{E B I T}{U I} \\
R O E(\text { s polugom })=\frac{E B I T-I-T(\text { s polugom })}{V G} \\
R O E(\text { bez poluge })=\frac{E B I T-T(\text { bez poluge })}{V G=U I}
\end{gathered}
$$

II. Slučaj (Case)

$$
\begin{gathered}
R O A(I I)=\frac{E B I T}{V G+K O} \\
R O E(\text { s polugom })=\frac{E B I T-I-T(\text { s polugom })}{V G} \\
R O E(\text { bez poluge })=\frac{E B I T-T(\text { bez poluge })}{V G+K O}
\end{gathered}
$$

III. Slučaj (Case)

$$
\begin{gathered}
R O A(I I I)=\frac{E B I T}{V G+K O+D} \\
R O E(\text { s polugom })=\frac{E B I T-I-T(\text { s polugom })}{V G} \\
R O E(\text { bez poluge })=\frac{E B I T-T(\text { bez poluge })}{V G+K O+D}
\end{gathered}
$$

Gdje je:

$\mathrm{T}=$ porez $20 \%$

$\mathrm{T}(\mathrm{s}$ polugom $)=20 \% * \mathrm{EBT}$

$\mathrm{T}$ (bez poluge $)=20 \%$ EBIT

$\mathrm{EBT}=\mathrm{EBIT}-\mathrm{I}$

EAT $($ s polugom $)=$ EBIT $-\mathrm{I}-\mathrm{T}(\mathrm{sp})$

EAT $($ bez poluge $)=$ EBIT $-\mathrm{T}(\mathrm{bp})$ 
U određivanju opravdanosti korištenja FP provedena je EBIT/EPS analiza, gdje je zarada po dionici izračunata prema izrazu:

$$
\text { EPS }=\frac{\text { Netodobit }}{\text { Vlastiti kapital }(\text { Glavnica })}
$$

U radu su korišteni podaci javnih financijskih izvještaja i javnih godišnjih poslovnih izvještaja Trgovačkog društva „Hrvatske šume“ d.o.o. Analizirani su podaci za razdoblje 2005.-2015. godina. Društvo gospodari glavninom šuma i šumskog zemljišta (2 mil. ha) u vlasništvu Republike Hrvatske. Sjedište Društva je u Zagrebu. Temeljni kapital iznosi: 1.171.670.000,00 kuna. Radi eliminacije drugih utjecaja na neto dobit korišten je izračun poreza na dobit kod kojega je jedina stavka poreznog zaklona iznos kamata. Primijenjena je jedinstvena stopa poreza na dobit od 20\%, koja je vrijedila kroz analizirano razdoblje. Kako porez na dobit ovisi i o određenim rashodima koji se ne priznaju kao odbitna stavka od oporezive dobiti, u radu je umjesto stvarnog iznosa poreza na dobit korišten izračun poreza korištenjem važeće stope na iznos dobiti nakon kamata. Na taj je način omogućeno sagledavanje poreznog zaklona koji je isključivo rezultat zaduživanja, odnosno uporabe financijske poluge.

\section{REZULTATI}

\section{RESULTS}

U rezultatima istraživanja prvo su prikazane i analizirane temeljne mjere određivanja uspješnosti korištenja financijske poluge: učinak financijske poluge, zarada po glavnici i stupanj financijske poluge. Zatim je obrađena opravdanost zaduživanja, efekte financijske poluge te naposljetku model oportunosti korištenja financijske poluge kroz opisana tri slučaja.

EBIT/EPS analizom ispitan je učinak financijske poluge na ponašanje EPS pri različitim razinama EBIT (Slika 1, 2).

Kretanje EPS u promatranom razdoblju može se podijeliti u dva perioda, prije i poslije 2011. godine (Slika 2). U oba perioda EPS je u obratnoj proporciji s učinkom financijske poluge (Slika 1). U prvom periodu učinak financijske poluge raste, a EPS je padajućeg trenda i razmjerno nizak, dok u drugom periodu učinak financijske poluge snažno pada dok EPS raste. Učinak financijske poluge bitno je uvjetovan veličinom zaduženosti i visinom kamata. Konkretno, učinak financijske poluge uvjetovan je visokim udjelom kamata u maloj bruto dobiti (EBIT) u prvom periodu, odnosno značajnim povećanjem bruto i neto dobiti te smanjenjem obveze i kamata u drugom periodu (Slika 3).

Kako bi se daljnje analizirao utjecaj financijske poluge na poslovni rezultat Hrvatskih šuma d.o.o., izračunati su pokazatelji stupnja financijske poluge (DFL). DFL kretanjem (Slika 4) u potpunosti odgovara kretanju učinka FP (Slika

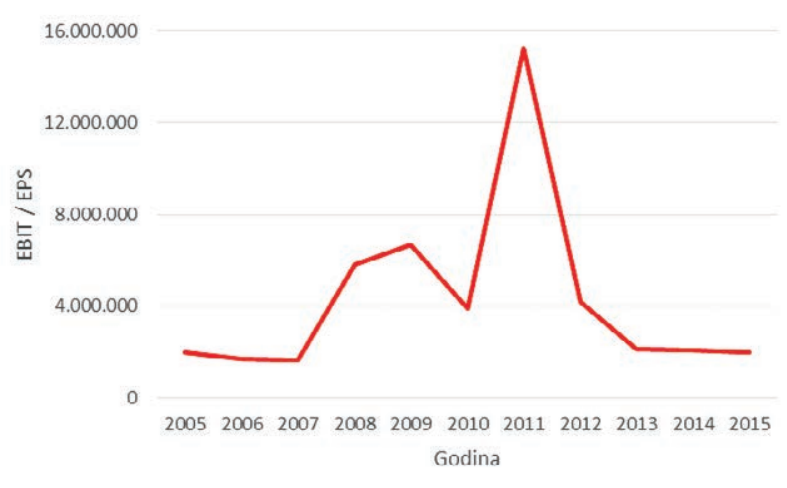

Slika 1: Učinak financijske poluge

Figure 1: Financial leverage effect

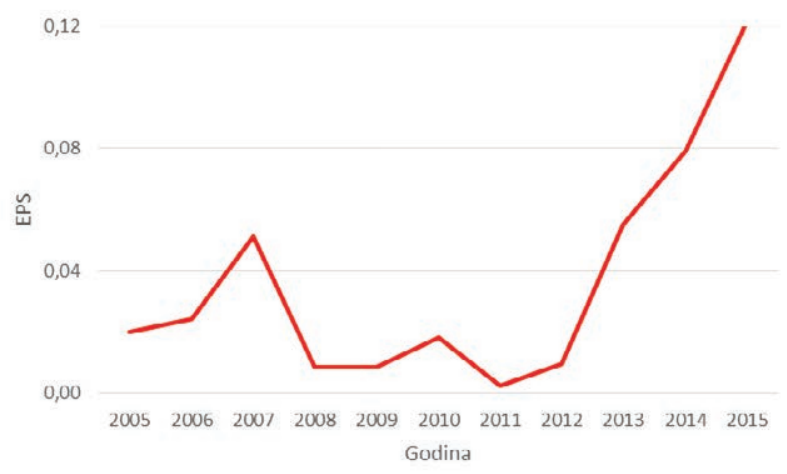

Slika 2: Zarada po glavnici (vlastitom kapitalu)

Figure 2: Earning per share (own capital)

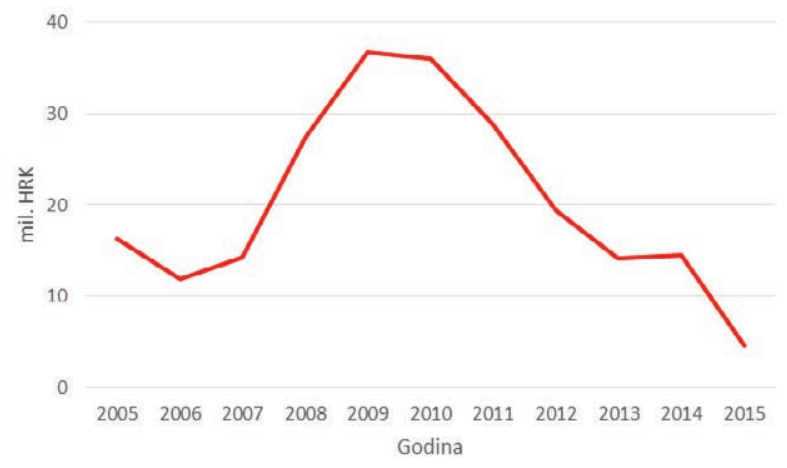

Slika 3: Kamate

Figure 3: Interests

1). Kretanje DFL je uvjetovano visokim udjelom kamata u EBIT (brojnik pokazatelja), a tim slijedom i velikim razlikama EBIT i EBT i relativno niskom razinom EBT (nazivnik) u prvom periodu do 2011. godine. U drugom periodu bilježi se značajno povećanje EBIT, kao i značajno smanjenje kamata, a time i značajno povećanje EBT. Posljedično, odnos bruto i neto dobiti približava se broju 1. Na kretanje DFL također utječe i ROA, koje pokazuje snažan rast u drugom periodu (Slika 5,7). 


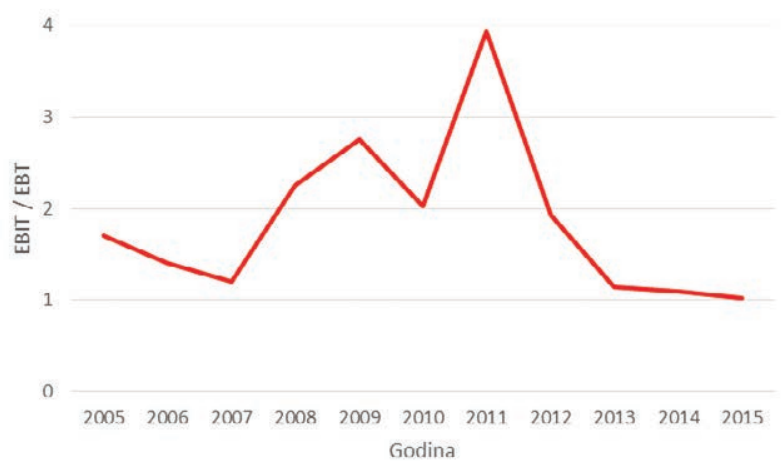

Slika 4: Stupanj financijske poluge

Figure 4: Degree of Financial Leverage

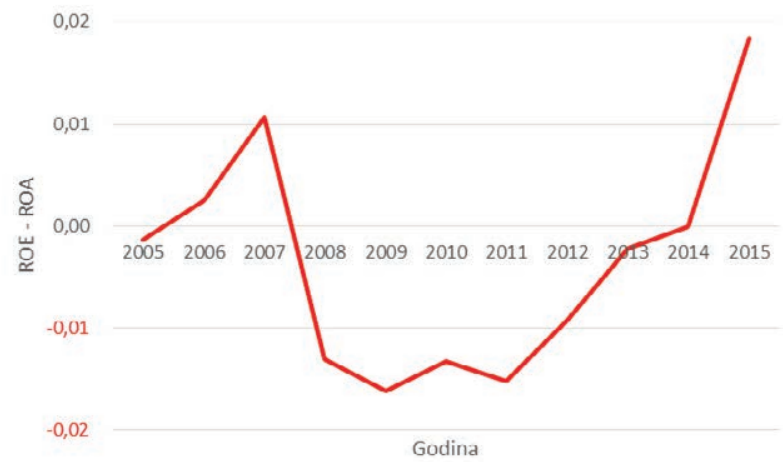

Slika 5: Opravdanost zaduživanja (ROE minus ROA)

Figure 5: Debt justification (ROE minus ROA)

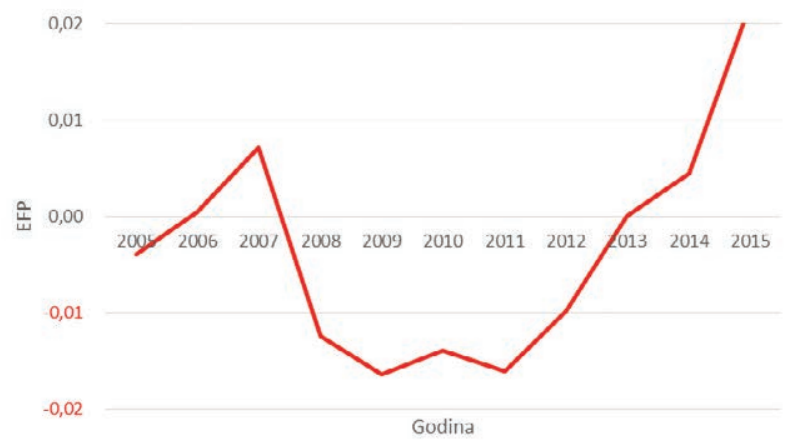

Slika 6: Efekt financijske poluge

Figure 6:The effect of financial leverage

U analizi učinka korištenja financijske poluge pokazatelji profitabilnosti (rentabilnosti) pokazuju isplati li se poduzeću koristiti financijskom polugom, odnosno zaduživati se ili ne. Ako je stopa profitabilnosti vlastitog kapitala (glavnice) viša od stope profitabilnosti imovine, isplati se koristiti dugove $\mathrm{u}$ financiranju poslovanja poduzeća. $\mathrm{U}$ analiziranom razdoblju ROE je veća od ROA 2006; 2007. i 2015. godine kada se smatra da je Poduzeće opravdano koristilo tuđe izvore financiranja (Slika 5).

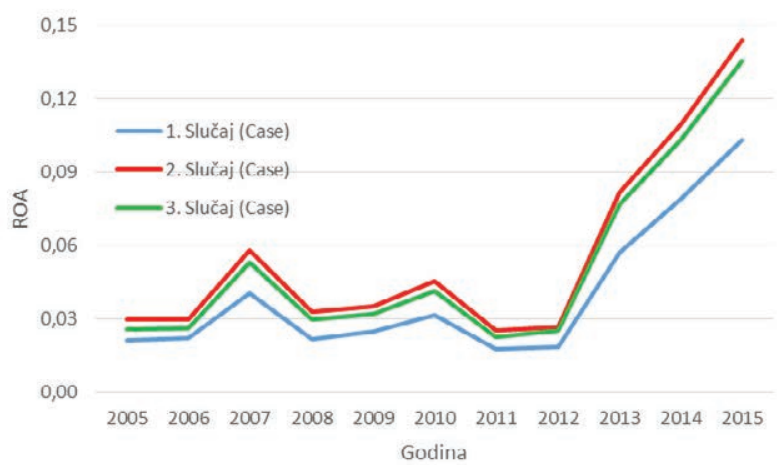

Slika 7: Rentabilnost imovine Figure 7:Return on asset

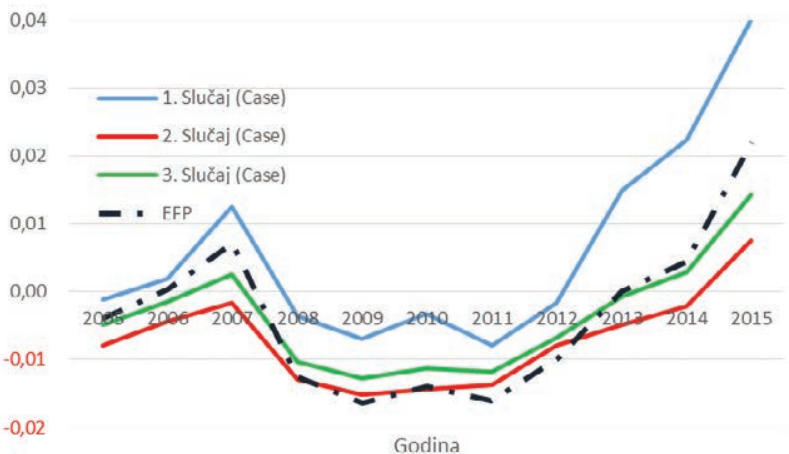

Slika 8: ROE s polugom minus ROE bez poluge

Figure 8: ROE with leverage minus ROE without leverage

Nešto drukčije, ali uglavnom slične rezultate daje i efekt financijske poluge (EFP), što je prikazano na slici 6. EFP je negativan 2005. godine te u periodu 2008.-2012. U tim godinama razlika između ROE i RIN je negativna, dakle, RIN je veća od ROE. Situaciju negativnog djelovanja EFP tj. nepovoljnog zaduženja, odražava i odnos u kojem je STTK veća od RIN. U navedenom periodu Poduzeće nije iskoristilo posuđena sredstva za stvaranje dovoljne količine budućih ekonomskih koristi. Upravo obrnuto, nedovoljna profitabilnost korištene imovine smanjila je profitabilnost za vlasnike uslijed korištenja financijske poluge.

Suprotno prethodnom, EFP je pozitivan u dva perioda, 2006.-2007. i 2013.-2015. U ovim periodima razlika između ROE i RIN je pozitivna, a STTK manja od RIN. U posljednjoj godini promatranog razdoblja EFP snažno raste (Slika 6.) Što upućuje na pozitivno korištenje financijske poluge. Dakle, u slučaju pozitivnog djelovanja EFP može se zaključiti kako je zaduživanje stvorilo pozitivne ekonomske koristi profitabilnim ulaganjem tako posuđenih sredstava i na taj način je korištenje financijske poluge bilo učinkovito.

Do sada je analiza korištenja financijske poluge rađena na bazi agregiranih stavki imovine, obveza i glavnice iz financijskih izvještaja poduzeća Hrvatske šume d.o.o. Korište- 
njem takvih podataka djelomično je zamagljena analiza oportunosti korištenja financijske poluge. Naime, spontano financiranje ne nosi kamate. Ono je rezultat odluka o poslovanju, a ne odluka o financiranju. Odlukom o financiranju poduzeće koristi obveze koje nose kamate, odnosno koje jednostavno „koštaju“. Tim odlukama poduzeće svjesno prihvaća određeni teret kamata koji definira cijena duga, odnosno kamatna stopa i sama veličina duga. Kada se teret kamata promatra na ukupne obveze, spontano financiranje zamagljuje stvarnu cijenu dugova jer smanjuje teret kamata. Zbog toga je u nastavku provedena modificirana analiza, u tri slučaja, odnosa ROA i ROE kako bi se pravilnije ocijenila uporaba financijske poluge kao svjesne financijske odluke o izboru načina financiranja.

Prvi slučaj pošao je od ukupne imovine te ukupnih obveza i glavnice. Drugi slučaj u analizu je uzeo isključivo kamatonosne obveze tako da je i ukupna imovina bila nužno umanjena za iznos nekamatonosnih obveza, što znači da je uzeta samo imovina financirana glavnicom $i$ kamatonosnim obvezama. Treći slučaj konstruiran je radi isticanja utjecaja dobavljača kao jednog od najznačajnijeg oblika spontanog financiranja. Kretanje rentabilnosti (profitabilnosti) imovine i razlike ROE s polugom ROE prikazano je na Slikama 7 i 8.

Slika 7 pokazuje rentabilnost (profitabilnost) imovine za tri analizirana slučaja. To su rentabilnost ukupne imovine (Slučaj 1), rentabilnost imovine financirane glavnicom i kamatonosnim obvezama (Slučaj 2) i rentabilnost imovine koja je financirana, osim glavnice i kamatonosnih obveza, i trgovačkim kreditima dobavljača (Slučaj 3). U promatranom razdoblju razvidni su pozitivni prinosi na imovinu sa snažnim rastom krajem promatranog razdoblja. Najmanja ROA je u Slučaju 1; koji prikazuje odnos bruto dobiti i ukupne imovine. Najveća ROA je u Slučaju 2; koji predstavlja odnos bruto dobit i sume VG+KO. U Slučaju 3; dodavanjem spontanog financiranja trgovačkim kreditima, tj. redefiniranjem imovine $\mathrm{VG}+\mathrm{KO}+\mathrm{D}$; ROA je neznatno manja u odnosu na Slučaj 2. Razlike prinosa na imovinu rezultat su različitih kategorija imovine uzetih u izračun ROA. Zbog toga je logično da je rentabilnost imovine najviša tamo gdje je najuži obuhvat imovine, a najmanja za slučaj ukupne imovine.

Iako je rentabilnost imovine u cijelom analiziranom razdoblju bila pozitivna, može se postaviti pitanje bi li uspjeh $\mathrm{Hr}-$ vatskih šuma d.o.o. bio bolji ili lošiji sa ili bez uporabe poluge. Zbog toga se u nastavku analizira prinos na vlasničku glavnicu kakav su Hrvatske šume d.o.o. ostvarile uz uporabu financijske poluge i prinos na vlasničku glavnicu koji bi bio bez upo

rabe poluge. Prinos na vlasničku glavnicu mjeren je pokazateljem rentabilnosti (profitabilnosti) glavnice. Nakon što su izračunati ROE s polugom i ROE bez poluge utvrđena je njihova razlika. Taj je rezultat prikazan je na Slici 8 . U sva tri slučaj Poduzeće je učinkovito koristilo posuđena sredstva tj. učinkovito koristilo vlastiti kapital krajem promatranog razdobljana, što ukazuje pozitivna razlika ROE s polugom i ROE bez poluge. Na neučinkovito korištenje posuđenih sredstava ukazuje negativna razlika ROE s polugom i ROE bez poluge.

\section{RASPRAVA I ZAKLJUČCI 4. DISCUSSION AND CONLUSIONS}

Oportunost korištenja financijske poluge uobičajeno se pokazuje odnosom prinosa na (vlasničku) glavnicu (ROE) i prinosa na ukupnu imovinu (ROA). U ovom radu je taj odnos mjeren razlikom ROE i ROA. Ako je razlika pozitivna, uporaba poluge bila je oportuna i obrnuto (Slika 5). Ovakva ocjena oportunosti uporabe poluge skriva zamku postojanja spontanog financiranja koje je rezultat poslovnih odluka, a ne odluke o izboru načina financiranja. Zbog toga je prva ideja rada bila ispitati učinkovitost analize oportunosti uporabe poluge modificiranim pokazateljem nazvanim efekt financijske poluge (Irraz 4, Slika 6). Deduktivnim pristupom, koji je potvrdilo i provedeno empirijsko istraživanje, zaključeno je kako i ovaj pokazatelj skriva istu zamku ocjene oportunosti uporabe poluge vezanu uz spontano financiranje. Zbog toga je na kraju modificirana standardna ROE / ROA analiza korištenjem opisana tri slučaja (Izraz 5-13, Slika 7,8). Definitivnu ocjenu oportunosti uporabe financijske poluge moguće je dati jedino korištenjem drugog slučaja gdje se prinosi na glavnicu i na imovinu promatraju samo odnosom ROE i ROA izračunatim za imovinu financiranu glavnicom i kamatosnosnim obvezama (Izraz 8-10).

U analiziranom razdoblju Hrvatske šume d.o.o. ostvarile su pozitivnu dobit i pozitivnu neto dobit (Slika 1,2,4). Iz toga bi se moglo zaključiti kako je njihovo poslovanje bilo uspješno. Naravno da bi zaključak o uspješnosti poslovanja trebalo temeljiti na tome je li takva dobit i neto dobit zadovoljavajuća sa stajališta vlasnika. Dodatno pitanje koje je i bilo predmetom ovog istraživanja odnosi se na to je li uporaba financijske poluge $u$ analiziranom poduzeću bila oportuna ili ne. Odgovor na to pitanje daje ocjenu upravljanja poduzećem sa stajališta izbora oblika financiranja. Drugim riječima je li menadžment poduzeća izborom financiranja uvećao ili smanjio zarade za vlasnike.

Standardna analiza odnosa ROE i ROA pokazala je kako je uporaba poluge bila oportuna samo u razdoblju 2006.-2007. godine i 2015. godine (Slika 5). Nešto drugačiju ocjenu daje uporaba pokazatelja efekt financijske poluge (Slika 6). Ključna razlika između ove dvije ocjene vezana je za intenzitet rezultata agregiranih pokazatelja.

Između tri prikazana slučaja jedino drugi slučaj pokazuje da je i u 2007. godini uporaba financijske poluge bila neu- 
činkovita (Slika 8). To je ispravan zaključak jer su u ostala dva slučaja besplatne obveze zamaglile zaključak o oportunosti poluge. Naime, kamatnosne obveze nosile su višu kamatnu stopu od, na odgovarajući način iskazane, ROA, tako da Poduzeće nije ostvarilo zadovoljavajući prinos na posuđena sredstva. Zbog toga je i rentabilnost glavnice manja uz korištenje poluge nego da se nisu koristili dugovi, čija je cijena bila previsoka u odnosu na ostvarene rezultate.

Nakon provedene analize oportunosti uporabe financijske poluge modificiranjem izračuna ROE i ROA za spontano financiranje može se donijeti i konačan zaključak o oportunosti uporabe financijske poluge u Hrvatskim šumama d.o.o.

Provedenom definitivnom analizom oportunosti korištenja financijske poluge (Slučaj 2) u Hrvatskim šumama d.o.o. u razdoblju 2005.-2015. zaključili smo kako je generalno menadžment loše koristio financijsku polugu. Drugim riječima menadžment je koristio dugove čija je cijena bila previsoka u odnosu na snagu zarađivanja poduzeća. Zbog toga su vlasnici poduzeća ostvarili manji prinos nego bi bio da se Poduzeće nije zaduživalo. Jedino je financijska poluga oportuno korištena u 2015. godini gdje su dugovi imali nižu kamatnu stopu od prinosa na imovinu.

Razloge neuspješnog korištenja financijske poluge ne treba tražiti samo u preskupim kreditima. Velik utjecaj na neuspješno korištenje financijske poluge imala je izrazito niska snaga zarađivanja poduzeća (Slika 2). Prijelomna točka siromašnog zarađivanja je 2012. godina od koje se bilježi njezin stalni rast. Upravo je rezultat ovog preokreta postizanje profitabilnosti imovine dovoljne da se uporaba financijske poluge može ocijeniti oportunom u zadnjoj godini analiziranog uzorka.

\section{LITERATURA}

5. REFERENCES

- Akerlof, G. A. (1970). The Market for „Lemons“: Quality Uncertainty and Market Mechanism, Quarterly Journal of Economics, Vol. 84, No. 3.

- Brealey. R. A., Stewart, C. M., Marcus, A. J., 2007. Osnove korporativnih financija. Prijevod. V izdanje. MATE. Zagreb.

- Durand, D., 1952. Cost of Debt and Equity Funds for Business: Trends and Problems of Measurement, Conference of Research in Business Finance, National Bureau of Economics Research, New York,

- Dvorski, S., Kovšca, V., 2011. Ekonomija za poduzetnike. TIVA. Varaždin.

- Gitman, Lawrence J., 2002. Principles of Managerial Finance, $10^{\text {th }}$ ed., Addison Wsley.
- Graham, J. R., Harvey, C. R., 2001. The Theory and Practice of Corporate Finance: Evidence from the Field, Journal of Financial Economics, Vol. 60.

- Helfert, E. A., 1991. Tehnike financijske analize. Prijevod. VII izdanje. Hrvatska zajednica računovođa i financijskih djelatnika.

- Jensen, Michael C., Mackling, William H., 1976. Theory of the Firm, Managerial Behavior, Agency Costs and Ownership Structure, Journal of Financial Economics, October.

- Ježovita, A., Žager, L., 2014. Ocjena zaduženosti poduzeća pokazateljima profitabilnosti. Zbornik EFZG 12/1. Zagreb.

- Klobučar, D. 2018. Investicijski projekti u zamjeni strojeva i opreme u TD „Hrvatske šume“ d.o.o. Magistarski rad. Fakultet organizacije i informatike u Varaždinu, Sveučilište u Zagrebu. Investment projects for the replacement of machines and equipment in commercial company „Hrvatske šume“ Ltd. Co. Master Thesis. The Faculty of Organization and Informatics Varaždin, University of Zagreb.

- Klobučar, D., Orsag, S., 2018. The influence of financial leverage on company business.International Scientific Conference. Sustainable forest management for the future - the role of managerial economics and accounting. IUFRO Unit 4.05.00 Managerial economics and accounting, Zagreb.

- Lízalová, L., Kozáková, P., 2013. Effect of the equity multiplier indicator in companies according to sectors. Acta Univ. Agric. Silvic. Mendelianae Brun. 2013, 61, 385-392

- Modigliani, F., Miller, M., 1958. The Cost of Capital, Corporation Finance and the Theory of Investment, American Economic Review, June

- Modigliani, F., Miller, M., 1963. Corporate Income Taxes and the Cost of Capital: A Correction, American Economic Review 53, June.

- Modigliani, F., Miller, M., 1969. Reply to Heins and Sprenkle American Economic Review, September.

- Myers, S., 1984. The Capital Structure Puzzle, The Journal of Finance, July, Volume XXXIX, no3.

- Orsag, S., 1982. Financijska poluga, Računovodstvo i financije, Zagreb, 7/82.

- Orsag, S., 2011. Vrijednosni papiri, Investicije i instrumenti financiranja, Revicon, Sarajevo.

- Orsag, S., 2015. Poslovne financije. Avantis. HUFA. Zagreb.

- Pecina, E., Orsag, S., 2014. Capital structure of Croatian enterprises, Proceedings of the Australian Academy of Business and Social Sciences Conference; in Partnership with The Journal of Developing Areas, The JDA, USA

- Pecina, E., 2018. Oblikovanje strukture kapitala i identifikacija ograničenja financiranja hrvatskih poduzeća, doktorski rad, Sveučilište u Zagrebu, Ekonomski fakultet - Zagreb.

- Rajan, R. G., Zingales, L., 1995. What Do We Know about Capital Structure? Some Evidence from International Dana, Journal of Finance, Vol. 50, No. 5.

- Shyam-Sunder, L., Myers, S. C., 1999. Testing Static Tradeoff Against Pecking Order Models of Capital Structure, Journal of Financial Economics, Vol. 51.

- http://portal.hrsume.hr/index.php/hr/ 


\section{SUMMARY}

Business success for business owners depends on the achieved earning power but also on choosing methods of financing their companies. Summing up, the opportunity of choosing methods of financing can be observed through the financial leverage rule. The rule states that the income for business owners can be increased through an opportune use of debt, in comparison to the income they would yield if the debt was not used.

This paper first examines possible approaches to the analysis of the opportune use of a financial leverage and isolates the best approach as the one which excludes the burden of spontaneous financing. After that, an analysis of concrete data of the company Croatian forests, Ltd is conducted, for the period between 2005 and 2015. The company manages most forests and forest land ( 2 million ha) owned by the Republic of Croatia. The company's headquarters is in Zagreb. The share capital is HRK 1.171.670.000.00.

The opportunity of using financial leverage is usually shown in the ratio of return on equity (ROE) and return on assets (ROA) (Table 1). The paper measures the ratio through the difference between ROE and ROA. If the difference is positive, the use of a leverage was opportune and vice versa (Figure 5). This type of assessment of opportune leverage use hides a burden of spontaneous financing which is a result of business decisions, and not the decision of methods of financing. Therefore, the first idea of the paper was to test the effectiveness of an analysis of an opportune use of a leverage through the modified indicator called the financial leverage effect (Expression 4, Figure 6). Through a deductive approach, which was also confirmed by the empirical research, we have concluded that this indicator also shows the same burden of the rating of the financial leverage use connected with spontaneous financing. For that reason, we modified the standard ROE/ROA analysis by using three cases. The first case started with complete assets and total liabilities and equity (Expression 5-7). The second case had only interest-bearing liabilities so that the total asset was decreased for the amount of non-interest-bearing liabilities, which means that only the asset financed by equity and interest-bearing liabilities was taken into consideration ( $E x$ pression 8-10). The third case was constructed for emphasizing the influence of suppliers as one of the most significant forms of spontaneous financing (Expression 11-13). The definite rating of an opportune use of financial leverage is possible only through using the second case where the yield on equity and asset is observed only through the ration of ROE and ROA calculated for assets financed by equity and interest-bearing liabilities.

In the analyzed time period, Croatian forests Ltd., achieved a positive result and a positive net profit (Figure 1,2,4). One possible conclusion might be that the company's business was successful. Naturally, the conclusion of a company's business success should be based on whether the net profit is satisfactory from the owner's point of view. An additional question, which was also the subject of this research, relates to the whether the use of a financial leverage in the analyzed company was opportune or not. The answer to that question is provided by the management's assessment of the choice of financing mode. In other words, whether the company's choice of financing has increased or reduced earnings for owners.

The standard analysis of the ROE and ROA ratio showed that the use of a leverage was opportune only between 2006 and 2007 and in 2015 (Figure 5). A somewhat different rating is given by the use of indicators of the financial leverage effect (Figure 6). The key difference between these two ratings is connected to the intensity of aggregated indicators. After the conducted analysis of the opportune use of financial leverage by modifying the calculation of ROE and ROA for spontaneous financing, a final conclusion can be made about the opportune use of financial leverage in Croatian forests Ltd. (Figure 7, 8).

Based on the definitive analysis of the opportunity to use the financial leverage (Case 2) in Croatian forests Ltd. in the period from 2005 to 2015 , we concluded that, the general speaking, the management used the financial leverage poorly. In other words, the management used debt whose price was too high in relation to the company's earning power. For this reason, the owners of the company made a smaller return than the company would have done, had it not been indebted. The only opportune financial leverage was used in 2015 where debt had a lower interest rate than the return on assets (Figure 8).

The reasons for the unsuccessful use of the financial leverage should not be sought only in excessive loans (Figure 3). A very low earning power had a huge impact on the unsuccessful use of the financial leverage (Figure 1,2). The breakthrough point for poor earnings was 2012, from which steady growth is recorded. It is precisely as the result of this turnaround that the achieved level of the profitability of assets was high enough that the use of financial leverage can be assessed as opportune in the last year of the analyzed sample (Figure 8).

KEY WORDS: forestry, effect of financial leverage, return on equity, return on asset, cost of debt 